\title{
The endemic plant species of Mt Kupe, Cameroon with a new Critically Endangered cloud-forest tree species, Vepris zapfackii (Rutaceae).
}

\section{Martin Cheek $^{1}$ \& Jean Michel Onana ${ }^{2,3}$}

\author{
${ }^{1}$ Science, Royal Botanic Gardens, Kew, Richmond, Surrey, U.K. Corresponding author. Email \\ address: m.cheek@kew.org \\ ${ }^{2}$ University of Yaoundé I, Faculty of Science, Department of Plant Biology P.O Box 812 Yaoundé, \\ Cameroon \\ ${ }^{3}$ IRAD-National Herbarium of Cameroon Yaoundé, PO Box 1601, Cameroon
}

Summary. We revise and update the records of strict and near-endemic species of Mt Kupe, Cameroon respectively from 31 strict endemics in 2004, to 25 today, and with near-endemic species 30, unchanged in number but with turnover. The changes result from new collections, discoveries and taxonomic changes in the last 16 years. While 15 of the provisionally named putative endemic species have now been formally published, a further 18 have not. The majority of the 30 near-endemic species (18) are shared with the adjacent Bakossi Mts, far exceeding the numbers shared with the more distant Mt Etinde-Mt Cameroon, Rumpi Hills and Ebo forest areas (sharing three near-endemic species each with Mt Kupe). We test the hypothesis that a further one of the provisionally named putative Mt Kupe species, Vepris sp. 1 from submontane forest near the summit, is indeed new to science. We compare it morphologically with the two other bicarpellate high altitude Cameroon Highland tree species Vepris montisbambutensis Onana and Vepris bali Cheek, concluding that it is a new undescribed species here named as Vepris zapfackii. The new species is illustrated, mapped and its conservation status assessed as Critically Endangered using the 2012 IUCN standard due to habitat clearance from agricultural pressures at its sole location which is unprotected. Vepris zapfackii and V. bali appear unique in African trifoliolate species of the genus in having opposite leaves. Vepris zapfackii differs in having hairy petiolules and midribs and petiolules with the blade decurrent distally, narrowing towards a winged-canaliculate base (vs glabrous and petiolule long, terete), and sparsely golden hairy pistillodes and a glabrous calyx (vs densely black hairy pistillodes, and sepals hairy).

Key words. Bakossi; Medicinal; Perhumid; submontane forest; threatened

\section{Introduction}

As part of the project to designate Important Plant Areas (IPAs) in Cameroon (also known as Tropical Important Plant Areas or TIPAs, https://www.kew.org/science/ourscience/projects/tropical-important-plant-areas-cameroon), we are striving to name, assess the conservation status and include in IPAs (Darbyshire et al. 2017) rare and threatened plant species in the threatened natural habitat of Cameroon. 
Several of these species were previously designated as new to science but not formally published in a series of checklists (see below) ranging over much of the Cross-Sanaga interval (Cheek et al. 2001). The Cross-Sanaga has the highest vascular plant species, and highest generic diversity per degree square in tropical Africa (Barthlott et al. 1996; Dagallier et al. 2020, respectively), including endemic genera such as Medusandra Brenan (Peridiscaceae, Breteler et al. 2015; Soltis et al. 2007). However, natural habitat is being steadily cleared, predominantly for agriculture. Eight hundred and fifteen species of vascular plant were Red Listed at the global level for Cameroon (Onana \& Cheek 2011).

In this paper we test the hypothesis that the Mt Kupe cloud-forest tree species formerly designated as "Vepris sp. 1" (Cheek et al. 2004), is a new species to science, and we describe, characterise, and name it as Vepris zapfackii Cheek \& Onana. The species is discussed in the context of revised and updated data on the endemic and near-endemic plant species of Mt Kupe, a known centre of plant diversity (see Discussion below).

Vepris Comm. ex A. Juss. (Rutaceae-Toddalieae), is a genus with 94 accepted species, 22 in Madagascar and 70 in Continental Africa with one species extending to Arabia and another endemic to India (Plants of the World Online, continuously updated). The genus was last revised for tropical Africa by Verdoorn (1926). Founded on the Flore du Cameroun account of Letouzey (1963), six new species were recently described from Cameroon (Onana \& Chevillotte 2015; Cheek et al. 2018a; Onana et al. 2019), taking the total in Cameroon to 24 species, the highest number for any country globally. By comparison, neighbouring Gabon has seven species (Sosef et al. 2006). Many of these 24 species are endemic to western Cameroon (SouthWest and NorthWest Regions of Cameroon) and several are threatened (Onana \& Cheek 2011) and in one case considered globally extinct (Cheek et al. 2018a), although only two currently appear on the IUCN Red List: Vepris lecomteana (Pierre) Cheek \& T. Heller (Vulnerable, Cheek 2004) and Vepris trifoliolata (Eng.) Mziray (Vulnerable, World Conservation Monitoring Centre 1998). In other parts of Africa species are even more highly threatened, e.g., the Critically Endangered Vepris laurifolia (Hutch. \& Dalz.) Lachenaud \& Onana of Guinea-Ivory Coast (formerly V. felicis Breteler, Cheek 2017a; Lachenaud \& Onana 2021).

In continental Africa, Vepris are easily recognised. They differ from all other Rutaceae because they have digitately (1-)3(-5)-foliolate (not pinnate) leaves, and unarmed (not spiny) stems. The genus consists of evergreen shrubs and trees, predominantly of tropical lowland evergreen forest, but with some species extending into submontane forests and some into drier forests and woodland. Vepris species are often indicators of good quality, relatively undisturbed evergreen forest since they are not pioneers (Cheek et al. 2019a). New species are steadily coming to light (Cheek et al. 2019a).

Species of Vepris in Africa extend from South Africa, e.g. Vepris natalensis (Sond.) Mziray, to the Guinean woodland in the fringes of the Sahara desert (Vepris heterophylla (Engl.) Letouzey). Mziray (1992) subsumed the genera Araliopsis Engl., Diphasia Pierre, 
Diphasiopsis Mendonça, Oricia Pierre, Teclea Delile, and Toddaliopsis Engl. into Vepris, although several species were only formally transferred subsequently (e.g., Cheek et al. 2009, Onana \& Chevillotte 2015). Mziray's conclusions were largely confirmed by the molecular phylogenetic studies of Morton (2017) but sampling was limited, identifications appeared problematic (several species appear simultaneously in different parts of the phylogenetic trees) and more molecular work would be desirable. Morton studied about 14 taxa of Vepris, mainly those from eastern Africa. Nevertheless, characteristics of some of the former genera are useful today in grouping species. The "araliopsoid" species have subglobose, 4-locular fruit with 4 external grooves; the "oricioid" species are apocarpous in fruit; the fruits of "diphasioid" species are laterally compressed in one plane, bilocular and bilobed at the apex; while "tecleoid" species are unilocular in fruit and 1-seeded, lacking external lobes or grooves. There is limited support for these groupings in Morton's study,

Due to the essential oils distributed in their leaves, and the alkaloids distributed in their roots, several species of Vepris have traditional medicinal value (Burkill 1997). Burkill details the uses, essential oils and alkaloids known from five species in west Africa: Vepris hiernii Gereau (as Diphasia klaineana Pierre), Vepris suaveolens (Engl.) Mziray (as Teclea suaveolens Engl.), Vepris afzelii (Engl.) Mziray (as Teclea afzelii Engl.), Vepris heterophylla (Engl.) Letouzey (as Teclea sudanica A. Chev.) and Vepris verdoorniana (Exell \& Mendonça) Mziray (as Teclea verdoorniana Exell \& Mendonça) (Burkill 1997: 651 - 653). Research into the characterisation and anti-microbial and anti-malarial applications of alkaloid and limonoid compounds in Vepris is active and ongoing, although sometimes published under generic names no longer in current use, e.g. Wansi et al. (2008).

Applications include as synergists for insecticides (Langat 2011). Cheplogoi et al. (2008) and Imbenzi et al. (2014) respectively list 14 and 15 species of Vepris that have been studied for such compounds. A review of ethnomedicinal uses, phytochemistry, and pharmacology of the genus Vepris was recently published by Ombito et al. (2021) although the identification of several of the species listed needs checking. Most recently, Langat et al. (2021) have published three new acridones and reported multi-layered synergistic anti-microbial activity from Vepris gossweileri (I.Verd.)Mziray, recently renamed as Vepris africana (Hook.f ex Benth.) Lachenaud \& Onana (Lachenaud \& Onana 2021).

\section{Materials \& Methods}

This study is based on herbarium specimens. All specimens cited have been seen. The methodology for the surveys in which the specimens were collected is given in Cheek \& Cable (1997). Herbarium citations follow Index Herbariorum (Thiers et al. continuously updated), nomenclature follows Turland et al. (2018) and binomial authorities follow IPNI (continuously updated). Material of the suspected new species was compared morphologically with material of all other African Vepris, principally at K, but also using material and images from BM, EA, BR, FHO, G, GC, HNG, P and YA. Specimens at WAG were viewed on the Naturalis website (https://bioportal.naturalis.nl/). The main online herbarium used during the study apart from that of WAG was that of P (https://science.mnhn.fr/all/search ). Points were georeferenced using locality information 
from herbarium specimens. The map was made using simplemappr (Shorthouse 2010). The conservation assessment was made using the categories and criteria of IUCN (2012). Herbarium material was examined with a Leica Wild M8 dissecting binocular microscope fitted with an eyepiece graticule measuring in units of $0.025 \mathrm{~mm}$ at maximum magnification. The drawing was made with the same equipment using a Leica 308700 camera lucida attachment.

\section{Results}

In the key to the Vepris species of Cameroon in Onana \& Chevillotte (2015), Vepris sp. 1 (Vepris zapfackii) keys to V. montisbambutensis Onana because of its non-winged petiole, lack of pulvini on the petiolules, three, thinly coriaceous leaflets which are less than $20 \times 6$ $\mathrm{cm}$, and which have brochidodromous venation, the lower surface marked by black points and also because of the ellipsoid fruits. Onana \& Chevillotte (2015) left the question open as to whether these two taxa are conspecific or not. However, the opposite leaves, hairy stems, petiolules and midribs of Vepris zapfackii clearly separate it from V. montisbambutensis. In these respects, it closely resembles Vepris bali Cheek, previously unique in tropical Africa in having opposite trifoliolate leaves. However, Vepris sp. 1 (Vepris zapfackii) can be separated from that species and further from $V$. montisbambutensis using the characters in Table 1 below. These three species are alone in the high altitude Vepris species of the Cameroon Highlands in the bifurcate pistillodes of the male flowers (not available in $V$. montisbambutensis) and the apocarpous bicarpellate fruits (not seen in Vepris bali).

\begin{tabular}{|c|c|c|c|}
\hline & $\begin{array}{l}\text { Vepris } \\
\text { montisbambutensis }\end{array}$ & Vepris bali & Vepris zapfackii \\
\hline Phyllotaxy & Leaves alternate & Leaves opposite & Leaves opposite \\
\hline Petiolule shape & Terete (cylindric) & Terete (cylindric) & Winged-canaliculate \\
\hline $\begin{array}{l}\text { Petiolule length } \\
(\mathrm{mm})\end{array}$ & $2-10$ & $9-14$ & $(1-) 2-6(-7)$ \\
\hline $\begin{array}{l}\text { Indumentum of } \\
\text { stems }\end{array}$ & Glabrous & Patent puberulent & Appressed hairy \\
\hline $\begin{array}{l}\text { Indumentum of } \\
\text { petioles }\end{array}$ & Glabrous & Glabrous & $\begin{array}{l}\text { Simple, spreading, } \\
\text { brown-hairy }\end{array}$ \\
\hline Petiole shape & Terete (cylindric) & Terete (cylindric) & Canaliculate \\
\hline Leaflet apex & $\begin{array}{l}\text { Shortly acuminate, } \\
\text { acumen to } 0.5 \mathrm{~cm} \text {, } \\
\text { entire }\end{array}$ & $\begin{array}{l}\text { Shortly acuminate, } \\
\text { acumen } 0.1-0.35 \\
\mathrm{~cm} \text {, entire (rarely } \\
\text { bifid), lacking a }\end{array}$ & $\begin{array}{l}\text { Shortly acuminate } \\
\text { acumen retuse, }(0.2 \\
-) 0.3-0.5(-0.6) \\
\text { cm with a central }\end{array}$ \\
\hline
\end{tabular}




\begin{tabular}{|l|l|l|l|}
\hline & & $\begin{array}{l}\text { central protrusion of } \\
\text { the midrib }\end{array}$ & $\begin{array}{l}\text { protrusion of the } \\
\text { midrib. }\end{array}$ \\
\hline $\begin{array}{l}\text { Pistillode of male } \\
\text { flower: indumentum }\end{array}$ & Not known & $\begin{array}{l}\text { Surface completely } \\
\text { covered in black, } \\
\text { bristle like hairs }\end{array}$ & $\begin{array}{l}\text { Surface partly } \\
\text { covered (c. 50\% of } \\
\text { surface) in scattered } \\
\text { golden hairs. }\end{array}$ \\
\hline $\begin{array}{l}\text { Sepal margin } \\
\text { indumentum }\end{array}$ & Not known & $\begin{array}{l}\text { Densely pectinate- } \\
\text { hairy }\end{array}$ & Glabrous \\
\hline $\begin{array}{l}\text { Median leaflet } \\
\text { dimensions }(\mathrm{cm})\end{array}$ & $\begin{array}{l}(2-) 3-9 \times(0.7- \\
1.5-3\end{array}$ & $6-10.5 \times 2.8-4.7$ & $\begin{array}{l}(4.5-) 6-9.5(-10) \\
\mathrm{x}(1.8-) 2.8-3.6(- \\
4.4)\end{array}$ \\
\hline
\end{tabular}

Table 1. Diagnostic characters separating montane or upper submontane Vepris tree species of Cameroon Highlands with bicarpellate apocarpous ovaries/pistillodes bifid and/or fruits apocarpous. Data for Vepris montisbambutensis from Onana \& Chevillotte (2015).

Vepris zapfackii Cheek \& Onana sp. nov. Type: Cameroon, South West Region, Mt Kupe, above Nyasoso, fr. June 1996, Zapfack 1005 (holotype K001394679; isotypes B, ETH, US, YA) (Fig. 1).

Syn. Vepris sp. 1 Cheek et al. (2004: 396).

Monoecious or dioecious evergreen shrub or tree $1-6 \mathrm{~m}$ tall. Trunk characteristics not recorded. Leafy stems terete, $3 \mathrm{~mm}$ diam. at most proximal leafy node, internodes $(1-) 1.5-$ $3.6(-5.5) \mathrm{cm}$ long, epidermis drying yellow-green, longitudinally fluted, moderately densely minutely appressed hairy, hairs simple, golden-brown, $0.05(-0.1) \mathrm{mm}$ long, at stem apex, covering c. $60 \%$ of the surface, gradually decreasing in density with distance from apex, c. $50 \%$ cover at third node from apex. Leaf phyllotaxy opposite and decussate, leaves with pleasant scent when crushed (Sebsebe 5097) trifoliolate, coriaceous, drying glossy green, 8.5 $-12 \mathrm{~cm}$ long, median leaflet oblanceolate, lateral leaflets $75-85 \%$ the length of the median, narrowly elliptic, elliptic-rhombic, or elliptic-oblanceolate, $(4.5-) 6-9.5(-10) \times(1.8-) 2.8$ $-3.6(-4.4) \mathrm{cm}$, apex shortly but distinctly acuminate, acumen $(0.2-) 0.3-0.5(-0.6) \mathrm{cm}$ long, apex of acumen minutely retuse, the cleft $0.5 \mathrm{~mm}$ deep, the cleft edges parallel, curving from the horizontal plane by 90 degrees abaxially, forming a $\mathrm{V}$-shape, the vertex abaxial, the margins thickened, revolute. (Fig. 1E), base of leaflet acute, decurrent as a wing to the distal half of the petiolule (Fig. 1C); margin thickened, revolute; secondary nerves, with midrib and tertiary nerves, raised, thickened, $(5-) 6-8$ on each side of the midrib, yellow-green, arising at $90^{\circ}$ from the midrib, arching towards the leaflet apex, forming a looping infra-marginal nerve c. $2 \mathrm{~mm}$ from the margin with a parallel, more minor infra-marginal nerve $<1 \mathrm{~mm}$ from the margin. Intersecondary nerves $1(-3)$, patent, extending towards margin before 
bioRxiv preprint doi: https://doi org/10.1101/2021.06 01.446645; this version posted June 2, 2021. The copyright holder for this preprint (which was not certified by peer review) is the author/funder, who has granted bioRxiv a license to display the preprint in perpetuity. It is made available under aCC-BY 4.0 International license.

Fig. 1. Vepris zapfackii. A. habit, fruiting branch; B. indumentum of leaflets; C. base of leaflets showing decurrent-winged canaliculate petiolules; D. Transverse section of petiolule-proximal part; E. retuse acumen; F. fruit with two apocarpous mericarps; G. gland dots on leaf abaxial surface; H. pistillode (male flower) side view; I. male flower, side view. A-G from Zapfack 1005 (K); H \& I from Ryan 407, drawn by HAZEL WILKS

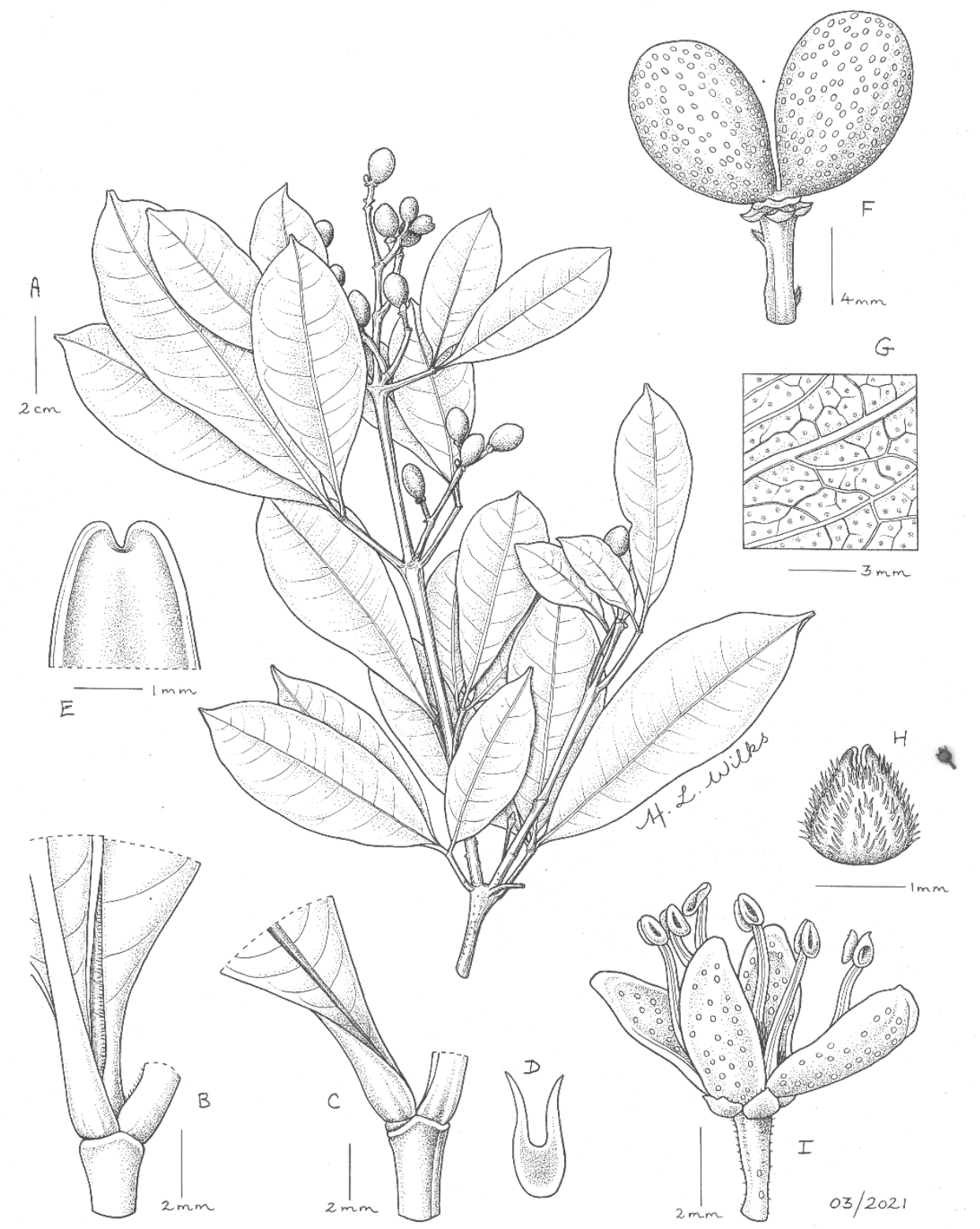


branching. Tertiary nerves inconspicuous, sparse; essential oil glands $(5-) 6(-7)$ per $\mathrm{mm}^{2}$, orbicular, $0.2 \mathrm{~mm}$ diam., appearing black on the abaxial surface (Fig. 1G); surfaces glabrous, except midrib (Fig. 1B) and near the petiolule, indumentum as petiolule (below); petiolules winged broadly distally, the wings becoming progressively narrower and erect in the proximal part, and laterally compressed and deeply canaliculate (Fig. 1D), $(0.1-) 0.2-0.6(-$ 0.7) $\mathrm{cm}$ long, with scattered simple, brown hairs $0.05 \mathrm{~mm}$ long (Fig. 1B), glabrescent. Petiole articulated with the petiolules of the three leaflets, shallowly canaliculate, $(1.2-) 1.4-2(-$ 2.9) $\mathrm{cm}$ long, $1.05-1.4 \mathrm{~mm}$ wide, hairs scattered, brown, $0.05 \mathrm{~mm}$ long, spreading, glabrescent. Male inflorescences (Female unknown) terminal, or in axillary pairs of the most distal nodes of the leafy stems, $5.5-7$ x $3-4.5 \mathrm{~cm}, 40-50$-flowered, peduncle $1.5-2.4 \mathrm{~cm}$ long; partial-peduncles opposite, in $2-4$ pairs along main axis, $1.2-1.7 \mathrm{~cm}$ long, rhachis internodes 3-5, 3-10 mm long; partial-inflorescences $1.5-3.5 \mathrm{~cm}$ long, bracts patent, narrowly triangular $0.5-0.55 \mathrm{~mm}$ long, margin with dense, long, translucent hairs, bracteoles 2 , subtended by the bracts, similar but smaller, c. $0.45 \mathrm{~mm}$ long. Pedicels $(1-) 1.5$ $-2(-2.8) \mathrm{mm}$ long, scattered with patent hairs $0.05 \mathrm{~mm}$ long. Flowers white, c. $3 \mathrm{~mm}$ wide (Fig. 1I). Sepals 4, broadly ovate or quadrate, slightly spreading and concave, c. 0.5 x 0.75 $\mathrm{mm}$, apex acute to obtuse, glabrous. Petals 4, elliptic-oblong, $4.5-4.9 \times 1.8-2 \mathrm{~mm}$, apex rounded, lacking appendages; oil glands orange, elliptic or orbicular, $0.1-0.2 \mathrm{~mm}$ diam., 7 20 scattered on abaxial and adaxial surfaces except for the scarious, $0.2 \mathrm{~mm}$ wide, very minutely hairy margin. Stamens 8 , equal, slightly exceeding petals, filaments $2.5-4(-4.5)$ $\mathrm{mm}$ long, ribbon-like; anthers ellipsoid, $0.75(-1)$ x $0.5 \mathrm{~mm}$. Pistillode (vestigial ovary), broadly ovoid to conical $1.25 \times 1.25 \mathrm{~mm}$, apex bifurcate, cleft $0.25 \mathrm{~mm}$ deep, drying black, with sparse to moderately dense spreading golden hairs $0.1-0.15 \mathrm{~mm}$ long covering c. $50 \%$ of the surface (Fig. 1H). Fruit (immature) apocarpous, mericarps 2 (sometimes 1 by abortion), barely united at the base (Fig. 1F), obovoid to ellipsoid, $0.9-1.0 \times 0.5-0.7 \mathrm{~cm}$, glabrous, surface with oil glands densely scattered, elliptic, $0.75 \times 0.5 \mathrm{~mm}$, apex rounded, apiculus absent.

RECOGNITION. Vepris zapfackii shares many similarities with Vepris bali Cheek, the two sharing the very unusual character in tropical African Vepris of opposite trifoliolate leaves. Both species also share a terminal paniculate inflorescence, and a hairy, bifid pistillode in the male flowers. They differ in that the petiolule of Vepris zapfackii is winged to deeply canaliculate throughout its length (vs terete), the petiole canaliculate (vs terete), the petioles, petiolules and midribs are sparsely hairy (vs glabrous), the sepals are glabrous (vs hairy), the pistillode is incompletely (c. $50 \%$ of the surface) covered in golden bristle hairs (vs completely covered in black hairs). In addition to the differential characters given in the diagnosis and Table 1, Vepris zapfackii also differs from Vepris bali in that the lateral leaflets are $75-80 \%$ the length of the median leaflet (vs c. 50\%), the median leaflets are usually narrowly elliptic or oblanceolate (not obovate), and the leaflet apices are usually minutely retuse, the sides of the cleft oriented at 90 degrees from the plane of the remainder of the leaflet (vs rarely retuse) and the midrib projects into the cleft as a small peg (not illustrated). It additionally differs from $V$. montisbambutensis in that the surface of the fruits is not foveolate but smooth, the gland dots are minute. However, it seems very likely that the three are sister species. Vepris montisbambutensis and V. bali occur to the north, and are separated 
by about 100 and $130 \mathrm{~km}$, respectively, from Vepris zapfackii along the length of the Cameroon Highlands. Vepris montisbambutensis is a point endemic restricted to the area of the Lebialem Highlands/Bamboutos Mts, and Vepris bali is, or was, endemic to high altitude in the Bali Ngemba Forest Reserve. Additional differential characters are given in Table 1 DISTRIBUTION. Cameroon, known only from the summit of Mt Kupe (at the border of South West and Littoral Regions) (Map 1).

SPECIMENS EXAMINED. CAMEROON. South West Region, Mt Kupe, above Nyasoso, fr. June 1996, Zapfack 1005 (B, ETH, K001394679, US, YA); ibid., above Kupe Village, 1940 m alt., Top of Kupe Mt, male fl. 30 May 1996, Ryan 407 (K000198298, MO, P, SCA, WAG, YA); ibid., towards the summit (peak 1) eastwards from the base camp (No. 2), immature fr., 11 Feb 1995, Sebsebe 5097 (K000198299, MO, P, WAG, YA).

HABITAT. Upper submontane forest dominated by Garcinia with many Rubiaceae (Sebsebe 5097), also with Zenkerella citrina Taub. c. $1940 \mathrm{~m}$ alt.

Map 1. Global distribution of Vepris zapfackii.

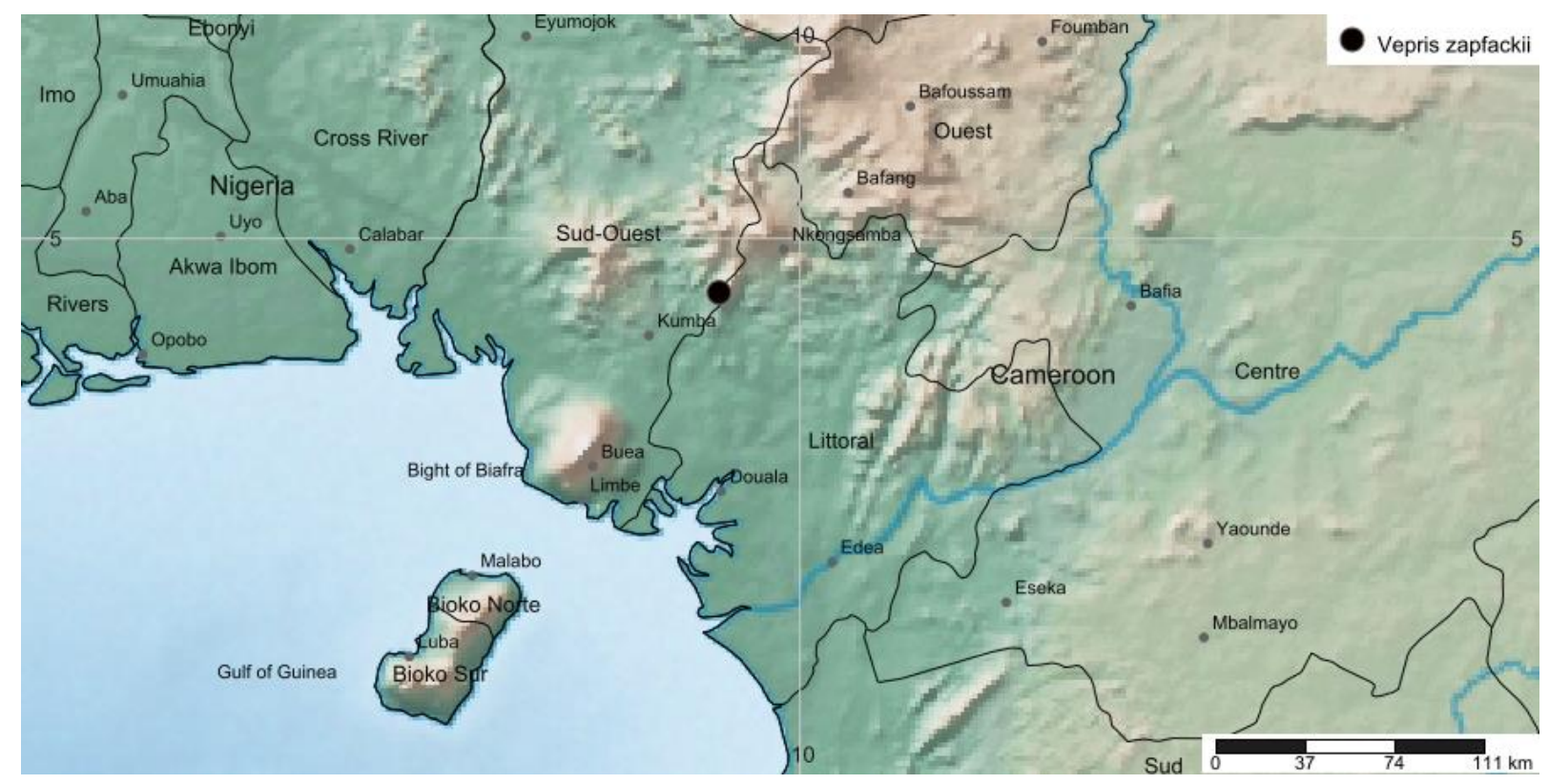

CONSERVATION STATUS. Vepris zapfackii is known from only three specimens all of which are confined to the forested summit area of Mt Kupe (2064 m), from personal experience at this location, the first author estimates the number of mature individuals of the species to be $<50$.

Mt. Kupe is not a formally protected area. The summit area is estimated to be $<4 \mathrm{~km}^{2}$. Clearance of forest for agriculture is continuing upslope at Mt Kupe. The greatest advance has occurred on the east side where it is already close to the summit. On the west side clearance has not yet been observed above $1500 \mathrm{~m}$ altitude but since there are no restrictions in place, the threat to rare, range-restricted species dependent on intact forest for survival is evident. Accordingly, we here assess Vepris zapfackii as Critically Endangered. CR B1+B2ab(iii)+D. 
It is possible that Vepris zapfackii will yet be found at additional locations in Cameroon. However, while surveys have not been exhaustive, many thousands of specimens have been collected in areas to the north, south, west and east of Mt Kupe, yet no additional specimens of this distinctive species have been found (Cheek et al. 1996; Cable \& Cheek 1998; Cheek et al. 2000; Maisels et al. 2000, Chapman \& Chapman 2001; Harvey et al. 2004; Cheek et al. 2004; Cheek et al. 2006; Cheek et al. 2010; Harvey et al. 2010; Cheek et al. 2011).

PHENOLOGY. Flowering in late May, immature fruits in February and June.

ETYMOLOGY. Named for Dr Louis Zapfack (1960 - ) who collected the type specimen of this species. Raised in Dschang, West Region, he is currently Professor in the Department of Plant Biology, Faculty of Science, University of Yaoundé I, where he is an ecologist and Climate Change Specialist (Carbon Stock evaluation). In the mid-1990s he led volunteer teams under the Earthwatch programme, linked with the "Plant Diversity of Western Cameroon" programme (Darwin Initiative), collecting many hundreds of herbarium specimens, including Vepris zapfackii. He is also commemorated by Bafutia tenuicaulis var. zapfackiana Beentje \& B.J. Pollard in Cheek et al. (2000: 92).

VERNACULAR NAMES \& USES. None are known.

\section{Discusssion}

\section{The Cameroon Highlands and Mt Kupe}

The Cameroon Highlands extend through four tropical African countries, along a fault line between two major African plates. Beginning in the south on the volcano island of Bioko (Equatorial Guinea) they continue on the mainland with the isolated Mount Cameroon active volcano (at $4095 \mathrm{~m}$ the highest point of the highlands), then heading $110 \mathrm{~km}$ NNE forming the ridges, plateaux and isolated peaks of the Bakossi Mts and Mts Kupe, Muanenguba, continuing NNE to the Ntale Mts of Banyang Mbo, the Lebialem Highlands and Bamboutos Mts, the Bamenda Highlands including Mt Oku (3011 m), Tchabal Mbabo, then heading eastwards and forming the lower and drier Adamaoua Highlands which extend into the Central African Republic. Two westward extending arms from the central section in Cameroon extend into Nigeria, forming the Obudu and Mambilla Plateaux. Four main mountain building periods, three volcanic and one plutonic have been reviewed by Courade (1974). Mt Kupe (2064 m) is mainly formed of syenite and granite with a basaltic cap (Enang et al. 2020) uplifted in the third, plutonic period, as was probably Mt Nlonako (1790 m) c. 30 $\mathrm{km}$ to the NE. The more extensive Bakossi Mts (1895 m) to the west, are uplifted preCambrian basement complex punctured by two small volcaniccraters, and are separated from Mt Kupe by the $5-10 \mathrm{~km}$ wide Chide trough fault. To the west of the Bakossi Mts, separated by the valley of the Mungo River, the Rumpi Hills are formed from ancient basalts and trachytes. The Chide trough, with its volcanic cinder cones producing fertile soils for agriculture, is comparatively densely populated. $25 \mathrm{~km}$ to the north of Mt Kupe is the $3-4$ $\mathrm{km}$ wide Mwanenguba caldera (2411 m) occupying the summit of a massive Hawaiian type volcano.

Mt Kupe is surrounded by a $4 \mathrm{~m}$ p.a. isohyet in Courade (1974) but rainfall varies from $3 \mathrm{~m}$ p.a. at the town of Loum on its SE corner, to 6-7 m p.a on the slopes of the SW (Sieffermann 1973 cited in Cheek et al. 2004). The main rainy season is May-October 
inclusive. All but two months, December and January have rainfall exceeding $100 \mathrm{~mm}$ at Tombel in the SW and Nyasoso in the W where relative humidity never falls below $80 \%$. However, measurements have only been made at settlements below and not on the mountain itself. Throughout the year the mountain is blanketed in cloud and there are only rare moments when this is lifted, such as immediately after a heavy thunderstorm. Submontane, also known as cloud forest is generally accepted to occupy the $800-2000 \mathrm{~m}$ altitudinal interval and covers the mountain in that range apart from some elements of montane forest and a few grassy spots at the summit where soil is too thin over rock surfaces to support trees, and also several large, vertical cliff faces, locally known as "rocks", which have a distinct community of plant species. Lowland forest at the $400-600 \mathrm{~m}$ foot of the mountain was mainly evergreen, but semi-deciduous in the SE. It has mainly been cleared for agriculture, especially coffee, Coffea canephora, Pierre ex Froehn., cacao, Theobroma cacao L., cabbage, Brassica oleracea L. and plantain Musa spp. (Stoffelen et al. 1997). However, remnants occur, with several point plant species endemics.

Twelve Bakossi villages surround the c. $42 \mathrm{~km}^{2}$ forest of Mt Kupe. Traditionally the summit of the mountain is considered the home of powerful spirits that can enslave humans, and is regarded as a fearsome and sacred place, and it is well-known throughout Cameroon for this reason (Wild in Cheek et al. 2004). However, a trail to the summit from Nyasoso (800 m) on the west side has been popular with ecotourists, especially those seeking to view the submontane bird species, the Mt Kupe Bush Shrike (Chlorophoneus kupeensis, formerly placed in Malaconotus and Telophorus) previously considered endemic to Mt Kupe but now known to occur also in the Bakossi Mts to the west and at two points in adjoining Nigeria. Less than 250 individuals are estimated to exist and it is assessed as Endangered (Birdlife International 2018).

Mt Kupe and the Bakossi Mts, together with the slopes of Mwanenguba, and the adjoining Ntale probably comprise the largest surviving area of submontane forest in both Cameroon and in Africa west of the East African rift mountains. Elsewhere in the Cameroon Highlands this vegetation has either been completely cleared for agriculture (the Bamileke Plateau and Bamboutos Mts) or reduced to small fragments (Lebialem, Bamenda and Mambilla Highlands) or due to lower humidity at higher latitudes, it appears absent as at Tchabal Mbabo and the Adamaoua Mts (Chapman \& Chapman 2001; Harvey et al. 2004; Harvey et al 2010). However, cloud forest also occurs on Mt Cameroon (Tchouto et al. 1999).

\section{The endemic plant species of Mt Kupe}

Unlike the well-known Mt Cameroon (Cheek et al. 1994; Cheek et al. 1996), Mt Kupe and the neighbouring Bakossi Mts were unknown to be centres of plant species diversity until the early $21^{\text {st }}$ Century when the "Conservation Checklist for the Plants of Kupe, Mwanenguba and the Bakossi Mountains" was published (Cheek et al. 2004). In one of the first papers foreshadowing this and reviewing knowledge of the rare species then known from Mt Kupe while describing a species then considered endemic to the mountain (Coffea montekupensis Stoff., Stoffelen et al. 1997), no other endemic species were noted although five rare and 
near-endemic species were listed and six new species were stated as being in the course of preparation for publication (Stoffelen et al. 1997). After the collection of many thousands of herbarium specimens in the late 1990s (including the specimens described in this paper), and subsequent identifications, large numbers of new species such as Vepris sp. 1, came to light and were recorded in Cheek et al. (2004).

Twenty-six strict endemics to Mt Kupe and 30 near endemics were recorded there from submontane forest (Cheek et al. 2004: 37 - 39) while three further strict endemics were recorded from montane habitat (Cheek et al. 2004: 58 \& 65) and two from lowland habitats (Cheek et al. 2004: 29). Many of the endemics were known under provisional names only. Since that time, many of these have been formally published. Some of the species previously thought to be endemic have been discovered at additional locations so that they are no longer either endemic to Mt Kupe (known only from Mt Kupe) or near-endemic (here defined as from Mt Kupe and one or two other locations). Examples of species previously considered endemic but no longer so are: Coffea montekupensis Stoffeln. (Stoffelen et al. 1997) now recorded not only from Mt Kupe and the Bakossi Mts, but from Ebo, Banyang Mbo and the Lebialem Highlands (Harvey et al. 2010:135). Similarly, Uvariopsis submontana Kenfack, Gosline \& Gereau (Kenfack et al. 2003) is now known from more than two locations apart from Mt Kupe although still rare and threatened. Mussaenda sp. nov. later published as $M$. epiphytica Cheek (Cheek 2009) is now also recorded from Mt. Etinde, Rumpi Hills \& Mbam Minkom (Lachenaud et al. 2013). Tricalysia sp. B aff. ferorum, published as Tricalysia elmar Cheek is now also recorded from Ngovayang \& Rumpi Hills (Cheek et al. 2020a). Psychotria sp. aff. camerunensis of Cheek et al. (2004), published as $P$. ngollengollei Cheek (Cheek et al. 2009) was reduced to a subspecies of $P$. solfiana K. Krause and shown also to be at Rumpi Hills, Banyang Mbo and Nlonako, apart from Mt. Kupe and Bakossi Mts (Lachenaud 2019). Dracaena sp. aff. phrynoides appears to be Dracaena bushii Damen with nine locations (Damen et al. 2018).

Other taxa formerly thought to be possibly new to science have subsequently been reidentified e.g. Friesodielsia enghiana var. nov. as Monanthotaxis glaucifolia (Hutch. \& Dalz.) P.H. Hoekstra, Monanthotaxis sp. nov. as Sphaerocoryne gracilipes (Beath.) X. Guo \& R.M.K. Saunders (Couvreur et al. 2021), and Bulbophyllum kupense P.J. Cribb \& B.J. Pollard (Cribb \& Pollard 2004) has been reduced to synonymy of B. teretifolium Schltr., still rare and threatened but recorded from Mbam Minkom, Rumpi Hills and Banyang Mbo in addition to Mt Kupe, so is no longer a near endemic (Droissart et al. 2012).

Below, in Table 2, we update the known endemics of Mt Kupe. In addition to those species originally documented as such in Cheek et al. (2004) often now under other names, we include species that had not been included there, but which have come to light subsequently, such as Psychotria asterogramma O. Lachenaud (Lachenaud 2019:150) endemic to Mt Kupe, Mt Cameroon and Bioko and Aframomum kamerunicum D.J. Harris \& Wortley, endemic to Mt Kupe and the Bakossi Mts (Harris \& Wortley 2018). 
bioRxiv preprint doi: https://doi org/101101/2021.06.01 446645; this version posted June 2,2021 . The copyright holder for this preprint

(which was not certified by peer review) is the author/funder, who has granted bioRxiv a license to display the preprint in perpetuity. It is made available under aCC-BY 4.0 International license.

Table 2. The strictly endemic plant species of Mt. Kupe, and those near-endemic, i.e. also at one or two other locations: the Bakossi Mts, Mt Nlonako, Lebialem Highlands or Ebo.

Revised and updated from Cheek et al. (2004: 37 - 39).

\begin{tabular}{|c|c|c|c|c|c|c|c|c|c|}
\hline Current name & $\begin{array}{l}\text { Previously } \\
\text { known as (e.g.in } \\
\text { Cheek et al. } \\
(2004))\end{array}$ & $\begin{array}{l}\text { Strictly } \\
\text { Endemic } \\
\text { to Mt } \\
\text { Kupe }\end{array}$ & $\begin{array}{l}\text { Also } \\
\text { Bako } \\
\text { ssi } \\
\text { Mts }\end{array}$ & $\begin{array}{l}\text { Also } \\
\text { Rumpi } \\
\text { Hills }\end{array}$ & $\begin{array}{l}\text { Also } \\
\text { Nlon } \\
\text { ako }\end{array}$ & $\begin{array}{l}\text { Also } \\
\text { Mt } \\
\text { Camer } \\
\text { oon- } \\
\text { Etinde }\end{array}$ & $\begin{array}{l}\text { Also } \\
\text { Leb } \\
\text { ialem } \\
\text { High- } \\
\text { lands }\end{array}$ & $\begin{array}{l}\text { Also } \\
\text { Ebo }\end{array}$ & Reference \\
\hline Diospyros kupensis & & & $\checkmark$ & & & & & & $\begin{array}{l}\text { Gosline \& } \\
\text { Cheek (1998) }\end{array}$ \\
\hline Drypetes sp.A & & & $\checkmark$ & & & & & & \\
\hline Eugenia sp. 1 & & & $\checkmark$ & & & & & & \\
\hline Coffea bakossii & & & $\checkmark$ & & & & & & $\begin{array}{l}\text { Cheek et } \\
\text { al. }(2002 \mathrm{a})\end{array}$ \\
\hline Ixora sp. A & & & $\checkmark$ & & & & & & \\
\hline Lasianthus sp. A & & & $\checkmark$ & & & & & & \\
\hline Pentaloncha sp. nov. & & & $\checkmark$ & & & & $\checkmark$ & & \\
\hline $\begin{array}{l}\text { Psychotria } \\
\text { bakossiensis }\end{array}$ & $\begin{array}{l}\text { Psychotria sp. A } \\
\text { aff.gabonica }\end{array}$ & & $\checkmark$ & & & & & & $\begin{array}{l}\text { Cheek \& Sonké } \\
\text { (2005a) }\end{array}$ \\
\hline Sericanthe sp. A & & & $\checkmark$ & & & & & & \\
\hline Tricalysia sp. F & & & $\checkmark$ & & & & & & \\
\hline $\begin{array}{l}\text { Rhaptopetalum } \\
\text { geophylax }\end{array}$ & & & $\checkmark$ & & & & $\checkmark$ & & $\begin{array}{l}\text { Cheek et } \\
\text { al. }(2002 \mathrm{~b})\end{array}$ \\
\hline Cola etugei & $\begin{array}{l}\text { Cola sp. nov. } \\
\text { 'etugei' }\end{array}$ & $\checkmark$ & & & & & & & $\begin{array}{l}\text { Cheek et al. } \\
(2020 \mathrm{~b})\end{array}$ \\
\hline Dracaena kupensis & $\begin{array}{l}\text { Dracaena cf. } \\
\text { phanerophlebia }\end{array}$ & & $\checkmark$ & & & $\checkmark$ & & & $\begin{array}{l}\text { Mwachala et } \\
\text { al.(2007) }\end{array}$ \\
\hline $\begin{array}{l}\text { Brachystephonus } \\
\text { kupeensis }\end{array}$ & & $\checkmark$ & & & & & & & $\begin{array}{l}\text { Champluvier \& } \\
\text { Darbyshire } \\
(2009)\end{array}$ \\
\hline $\begin{array}{l}\text { Justicia sp. } 1 \\
\text { (Ngomboku) }\end{array}$ & & $\checkmark$ & & & & & & & \\
\hline Drypetes sp. B & & $\checkmark$ & & & & & & & \\
\hline $\begin{array}{l}\text { Memecylon } \\
\text { kupeanum }\end{array}$ & Memecylon sp. 1 & $\checkmark$ & & & & & & & $\begin{array}{l}\text { Stone } e t \\
\text { al. }(2008)\end{array}$ \\
\hline Ardisia koupensis & & & & & $\checkmark$ & & & & \\
\hline
\end{tabular}


bioRxiv preprint doi: https://doi.org/10.1101/2021.06.01.446645; this version posted June $2,2021$. The copyright holder for this preprint (which was not certified by peer review) is the author/funder, who has granted bioRxiv a license to display the preprint in perpetuity. It is made available under aCC-BY 4.0 International license.

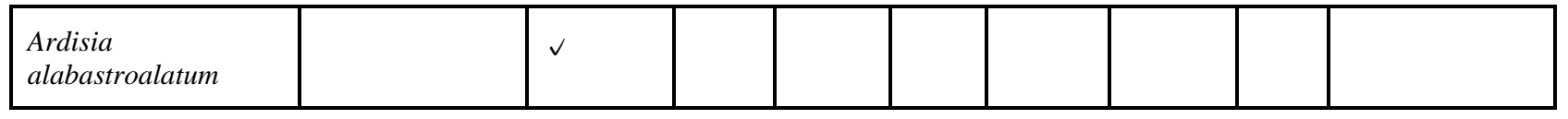

\begin{tabular}{|c|c|c|c|c|c|c|c|}
\hline Eugenia sp. 2 & & $\checkmark$ & & & & & \\
\hline Kupeantha kupensis & $\begin{array}{l}\text { Calyco- } \\
\text { siphonia sp. A }\end{array}$ & $\checkmark$ & & & & & $\begin{array}{l}\text { Cheek et al. } \\
(2018 b)\end{array}$ \\
\hline Ixora sp. B & & $\checkmark$ & & & & & \\
\hline $\begin{array}{l}\text { Psychotria sp. aff. } \\
\text { dorotheae }\end{array}$ & & $\checkmark$ & & & & & \\
\hline $\begin{array}{l}\text { Psychotria sp. B aff. } \\
\text { leptophylla }\end{array}$ & & $\checkmark$ & & & & & \\
\hline Rytigynia sp. B & & $\checkmark$ & & & & & \\
\hline Rytigynia sp. C & & $\checkmark$ & & & & & \\
\hline Tricalysia sp. C & & $\checkmark$ & & & & & \\
\hline Vepris zapfackii & Vepris sp. 1 & $\checkmark$ & & & & & (this paper) \\
\hline Pancovia sp. 1 & & $\checkmark$ & & & & & \\
\hline Microcos magnifica & $\begin{array}{l}\text { Microcos sp. } \\
\text { A }\end{array}$ & & & & & $\checkmark$ & Cheek (2017b) \\
\hline Afrothismia kupensis & $\begin{array}{l}\text { Afrothismia } \\
\text { pachyantha } \\
\text { s.l. }\end{array}$ & $\checkmark$ & & & & & $\begin{array}{l}\text { Cheek et al. } \\
(2019 b)\end{array}$ \\
\hline Afrothismia saingei & & $\checkmark$ & & & & & Franke (2004) \\
\hline Afrothismia fungiformis & & & & & & $\checkmark$ & $\begin{array}{l}\text { Sainge et al. } \\
\text { (2013) }\end{array}$ \\
\hline Costus kupeensis & Costus sp. A & & & & & $\checkmark$ & $\begin{array}{l}\text { Maas-van der } \\
\text { Kamer } \text { et al. } \\
\text { (2016) }\end{array}$ \\
\hline $\begin{array}{l}\text { Cyperus tenuiculmis } \\
\text { subsp. mutica }\end{array}$ & & $\checkmark$ & & & & & \\
\hline Bulbophyllum jaapii & & $\checkmark$ & & & & & $\begin{array}{l}\text { Szlachetho \& } \\
\text { Olsewski } \\
\text { (2001) }\end{array}$ \\
\hline Polystachya kupensis & & $\checkmark$ & & & & & $\begin{array}{l}\text { Cribb \& } \\
\text { Pollard (2002) }\end{array}$ \\
\hline Kupea martinetugei & & & & & $\checkmark$ & & $\begin{array}{l}\text { Cheek et al. } \\
(2003)\end{array}$ \\
\hline $\begin{array}{l}\text { Aframomum } \\
\text { kamerunicum }\end{array}$ & & & $\checkmark$ & $\checkmark$ & & & $\begin{array}{l}\text { Harris \& } \\
\text { Wortley (2018) }\end{array}$ \\
\hline
\end{tabular}




\begin{tabular}{|l|l|l|l|l|l|l|l|l|l|}
\hline Cyperus microcristatus & & $\checkmark$ & & & & & & & $\begin{array}{l}\text { Lye \& Pollard } \\
(2006)\end{array}$ \\
\hline Psydrax bridsoniana & & $\checkmark$ & & & & & & & $\begin{array}{l}\text { Cheek \& } \\
\text { Sonké } \\
(2005 \text { b })\end{array}$ \\
\hline Psychotria darwiniana & $\begin{array}{l}\text { Psychotria sp. } \\
\text { aff. alatipes }\end{array}$ & & $\checkmark$ & $\checkmark$ & & & & & $\begin{array}{l}\text { Cheek } \text { et al. } \\
\text { (2009) }\end{array}$ \\
\hline Pavetta kupensis & & & $\checkmark$ & & & & & & $\begin{array}{l}\text { Manning } \\
\text { (1996) }\end{array}$ \\
\hline Lefebvrea kupense & $\begin{array}{l}\text { Peucedanum } \\
\text { kupense }\end{array}$ & $\checkmark$ & & & & & & & $\begin{array}{l}\text { Cheek } \text { et al. } \\
\text { (2004) }\end{array}$ \\
\hline Dissotis sp. 1 & & $\checkmark$ & & & & & & & \\
\hline Psychotria cheekii & $\begin{array}{l}\text { Psychotria sp. } \\
9\end{array}$ & & & $\checkmark$ & & & & & $\begin{array}{l}\text { Lachenaud } \\
\text { (2019) }\end{array}$ \\
\hline $\begin{array}{l}\text { Psychotria } \\
\text { asterogramma }\end{array}$ & & & & & & $\checkmark$ & & & $\begin{array}{l}\text { Lachenaud } \\
(2019)((\text { also } \\
\text { Bioko) }\end{array}$ \\
\hline TOTALS & & 25 & 15 & 3 & 1 & 3 & 2 & 3 & \\
\hline
\end{tabular}

Examination of Table 2 shows that the number of strict endemics on Mt Kupe is now 25, a drop of six from the 31 in Cheek et al. (2004). This change has resulted from further survey work in other locations which has extended the known ranges of the species concerned so that they are no longer strict endemics. It has also resulted from taxonomic revisions and floristic studies that have reduced to synonymy three of the previously supposed strict endemics.

The number of near-endemics for Mt Kupe at 30, remains the same as in 2004. However, there has been some turnover with replacement on the list of formerly supposed near endemics since found to have wider ranges, with both former strict endemics now found to be near endemics and four newly published near endemic taxa that had not been listed as endemics in 2004, even under provisional names.

By far the majority of near-endemics (18/30) of Mt Kupe are shared with the Bakossi Mts only $5-10 \mathrm{~km}$ to the west. This number can be expected to increase if botanical surveys are continued since the Bakossi Mts are far from comprehensively studied: much of its vast area remains unvisited by botanists. Yet the Bakossi Mts have many endemics that do not extend to Mt Kupe, e.g. Impatiens frithii Cheek (Cheek \& Csiba 2002). Those near-endemics shared with the more distant Mt Cameroon and Rumpi Hills, only three each, reflect their greater geographical separation. Unexpectedly an equal number of near-endemics (3) are shared with the Ebo Forest, not formerly considered part of the Cameroon Highlands, c. $100 \mathrm{~km}$ to the SSE and which also has its own strict endemics, documented in Cheek et al. 2018c, with new additions currently being added (Gosline et al. 2021; Cheek et al. 2021). The very 
unexpected low number (1) shared with Mt Nlonako likely reflects low survey effort at this location.

While 15 of the provisionally named supposed endemics of Cheek et al. (2004) have now been formerly published (11 of which remain endemic or near-endemic) a further 18 (of which 11 are strictly endemic) remain unpublished. This paper continues the effort to address this deficit.

Formal publication of provisionally named endemics is a high priority since until species receive a scientific name, it is difficult for their conservation assessments to be placed on the IUCN Red List. Although formal protection of Mt Kupe was thought to be imminent in 2004 (Cheek et al. 2004), this has proved not to be the case. Instead, forest clearance for agriculture has continued increasing upslope reaching $1500 \mathrm{~m}$ alt. in some places (Birdlife International 2018). As such, the endemic plant species that depend upon it must all be considered threatened.

\section{Conclusions}

About 2000 new species of vascular plant have been discovered by science each year for the last decade or more adding to the estimated 369000 already known (Nic Lughadha et al. 2016), although the number of flowering plant species known to science is disputed (Nic Lughadha et al. 2017). Until species are delimited and known to science, it is more difficult to assess them for their conservation status and so the possibility of protecting them is reduced (Cheek et al. 2020c). In the main, the majority of new species described today tend to be range-restricted, making them especially likely to be threatened, although there are some exceptions (e.g. Cheek \& Etuge 2009). To maximise the survival prospects of rangerestricted species there is an urgent need not only to document them formally in compliance with the requirements of the relevant nomenclatural code (Turland et al. 2018), but also to formally assess the species for their extinction risk, applying the criteria of a recognised system, of which the IUCN Red List of Threatened Species is the most widely accepted (Bachman et al. 2019). Despite rapid increases over recent years in numbers of plant species represented by assessments on the Red List, the vast majority of plant species still lack such assessments (Nic Lughadha et al. 2020). Documented extinctions of plant species are increasing (Humphreys et al. 2019) and recent estimates suggest that as many as two fifths of the world's plant species are now threatened with extinction (Nic Lughadha et al. 2020). In Cameroon Oxygyne triandra Schltr. is globally extinct as is Afrothismia pachyantha Schltr. (Cheek \& Williams 1999; Cheek et al. 2018d; Cheek et al. 2019b), and at least two species of the African genus Inversodicraea (Cheek et al. 2017). In some cases, species appear to be extinct even before they are named for science, such as Vepris bali Cheek (Cheek et al. 2018a), and in neighbouring Gabon, Pseudohydrosme bogneri Cheek \& Moxon-Holt ined. (Moxon-Holt \& Cheek 2021). Most of the >800 Cameroonian species in the Red Data Book for the plants of Cameroon are threatened with extinction due to habitat clearance or degradation, especially of forest for small-holder and plantation agriculture e.g. oil palm, following logging (Onana \& Cheek 2011). Efforts are now being made to delimit the highest 
priority areas in Cameroon for plant conservation as Tropical Important Plant Areas (TIPAs) using the revised IPA criteria set out in Darbyshire et al. (2017).

National governments and leaders have recognised the importance of species assessed as threatened on the Red List and documented in IPAs or TIPAs as demonstrated recently in Cameroon when in part due to the high number of plant species on the Red List for the Ebo TIPA (Lovell 2020), a logging concession was revoked for the Ebo forest (Kew Science News 2020).

It is hoped that formal publication and Red Listing of additional endemic species such as the Critically Endangered Vepris zapfackii will help support the case for Mt Kupe being evidenced as a TIPA and gaining formal protection to help avoid the risk of global extinction of the 55 endemic plant species currently documented there, of which 25 are globally unique to the mountain on current evidence.

\section{Acknowledgements}

The specimens cited in this paper were collected by or with the support of volunteers and sponsored scientists arranged by Earthwatch Europe, Oxford, including Sebsebe Demissew, Louis Zapfack, P. Ryan, C. Moloney, and G. Adamu, and we were also assisted greatly by our Bakossi colleagues such as Daniel Ajang and the late Martin Etuge. George Gosline and Stuart Cable of Royal Botanic Gardens, Kew gave invaluable support at Mt Kupe as did Chris and Liz Bowden of the former Mt Kupe Forest Project (Birdlife International). Drs Satabie, Achoundong and more recently Florence Ngo Ngwe, Eric Nana, Jean Betti Lagarde, the current and former directors, of IRAD-National Herbarium of Cameroon, Yaoundé, and their staff are thanked for expediting the collaboration between our two institutes. Janis Shillito typed the manuscript. Two anonymous reviewers are thanked for constructively reviewing an earlier version of this paper.

\section{References}

Bachman, S.P., Field, R., Reader, T., Raimondo, D., Donaldson, J., Schatz, G.E. and Lughadha, E.N. (2019). Progress, challenges and opportunities for Red Listing. Biological Conservation 234: 45 - 55. https://doi.org/10.1016/j.biocon.2019.03.002

Barthlott, W., Lauer, W. \& Placke, A. (1996). Global distribution of species diversity in vascular plants: towards a world map of phytodiversity. Erdkunde 50: 317 327 https://doi.org/10.1007/s004250050096

BirdLife International. (2018). Chlorophoneus kupeensis. The IUCN Red List of Threatened Species 2018: e.T22707678A131946198. https://dx.doi.org/10.2305/IUCN.UK.20182.RLTS.T22707678A131946198.en. (Downloaded on 23 May 2021).

Breteler, F.J., Bakker, F.T. \& Jongkind, C.C. (2015). A synopsis of Soyauxia (Peridiscaceae, formerly Medusandraceae) with a new species from Liberia. Plant Ecology and Evolution. 148: 409 - 419. https://doi.org/10.5091/plecevo.2015.1040 
bioRxiv preprint doi: https://doi org/10.1101/2021.06.01.446645; this version posted June 2,2021 . The copyright holder for this preprint (which was not certified by peer review) is the author/funder, who has granted bioRxiv a license to display the preprint in perpetuity. It is made available under aCC-BY 4.0 International license.

Burkill, H.M. (1997). The Useful Plants of West Tropical Africa. Vol. 4, families M-R. Royal Botanic Gardens, Kew.

Cable, S. \& Cheek, M. (1998). The Plants of Mt Cameroon, a Conservation Checklist. Royal Botanic Gardens, Kew.

Champluvier, D. \& Darbyshire, I. (2009). A revision of the genera Brachystephanus and Oreacanthus (Acanthaceae) in tropical Africa. Syst. \& Geogr. Pl. 79: 115-192. https://doi.org/10.2307/25746.

Chapman, J. \& Chapman, H. (2001). The Forests of Taraba and Adamawa States, Nigeria an Ecological Account and Plant Species Checklist. University of Canterbury: Christchurch, New Zealand. pp. 221.

Cheek, M. (2004). Vepris lecomteana. The IUCN Red List of Threatened Species 2004: e.T46174A11039677. https://dx.doi.org/10.2305/IUCN.UK.2004.RLTS.T46174A11039677.e n. (Downloaded on 22 May 2021).

Cheek, M. (2009). Mussaenda epiphytica sp. nov. (Rubiaceae_) an epiphytic shrub from cloud forest of the Bakossi Mts, western Cameroon. Nordic J. Bot. 27: 456 - 459. https://doi.org/10.1111/j.1756-1051.2009.00576.x

Cheek, M. (2017b). Microcos magnifica (Sparrmanniaceae) a new species of cloud forest tree from Cameroon. PeerJ 5:e4137 https://doi.org/10.7717/peerj.4137

Cheek, M. (2017a). Vepris felicis. The IUCN Red List of Threatened Species 2017: e.T65064584A65064590. http://dx.doi.org/10.2305/IUCN.UK.20173.RLTS.T65064584A65064590.en. (accessed: 05/2021).

Cheek, M. \& Cable, S. (1997). Plant Inventory for conservation management: the KewEarthwatch programme in Western Cameroon, 1993 - 96, pp. 29 - 38 in Doolan, S. (Ed.) African Rainforests and the Conservation of Biodiversity, Earthwatch Europe, Oxford.

Cheek, M. \& Csiba, L. (2002). A new epiphytic species of Impatiens (Balsaminaceae) from western Cameroon. Kew Bull. 57: 669 - 674. https://doi.org/10.2307/4110997

Cheek, M. \& Etuge, M. (2009). A new submontane species of Deinbollia (Sapindaceae) from Western Cameroon and adjoining Nigeria. Kew Bull. 64: 503 - 508. https://doi.org/10.1007/s12225-009-9132-4

Cheek, M. \& Sonke, B. (2005a). Two further new species of Psychotria (Rubiaceae) from western Cameroon. Kew Bull. 60: 293 - 300. https://doi.org/10.2307/4111114

Cheek, M. \& Sonke, B. (2005b). Psydrax bridsoniana (Rubiaceae), a new species of tree from western Cameroon. Kew Bull. 59: 605 - 608. https://doi.org/10.2307/4110919 
bioRxiv preprint doi: https://doi.org/10.1101/2021.06.01.446645; this version posted June 2,2021 . The copyright holder for this preprint (which was not certified by peer review) is the author/funder, who has granted bioRxiv a license to display the preprint in perpetuity. It is made available under aCC-BY 4.0 International license.

Cheek, M., Williams, S. (1999). A Review of African Saprophytic Flowering Plants. In: Timberlake, Kativu eds. African Plants. Biodiversity, Taxonomy \& Uses. Proceedings of the 15th AETFAT Congress at Harare. Zimbabwe, 39 - 49.

Cheek, M., Achoundong, G., Onana, J-M., Pollard, B., Gosline, G., Moat, J., Harvey, Y.B. (2006). Conservation of the Plant Diversity of Western Cameroon. In: Ghazanfar SA, H.J. Beentje (eds). Proceedings of the 17th AETFAT Congress, Addis Ababa. Ethiopia, 779 - 791.

Cheek, M., Alvarez-Agiurre, M.G., Grall, A., Sonké, B., Howes, M-J.R., Larridon, L. (2018b). Kupeantha (Coffeeae, Rubiaceae), a new genus from Cameroon and Equatorial Guinea. PLoS ONE 13: 20199324. https://doi.org/10.1371/journal.pone.0199324

Cheek, M., Cable, S., Hepper, F.N., Ndam, N., Watts, J. (1996). Mapping plant biodiversity on Mt. Cameroon. In: Maesen, Burgt, Rooy eds. The Biodiversity of African Plants (Proceedings XIV AETFAT Congress. Cameroon: Kluwer, 110 - 120. https://doi.org/10.1007/978-94-009-0285-5_16

Cheek, M., Causon, I., Tchiengue, B. \& House, E. (2020a). Notes on the endemic cloud forest plants of the Cameroon Highlands and the new, Endangered, Tricalysia elmar (Coffeeae-Rubiaceae). Plant Ecology and Evolution 153: 167 - 176 https://doi.org/10.5091/plecevo.2020.1661

Cheek, M., Corcoran, M. \& Horwath, A. (2009). Four new submontane species of Psychotria (Rubiaceae) with bacterial nodules from western Cameroon. Kew Bull. 63: 405 - 418. https://doi.org/10.1007/s12225-008-9056-4

Cheek, M., Csiba, L. \& Bridson, D. (2002). A new species of Coffea (Rubiaceae) from western Cameroon. Kew Bull. 57: 675 - 680. https://doi.org/10.2307/4110998

Cheek, M., Etuge, M. \& Williams, S. (2019b). Afrothismia kupensis sp. nov. (Thismiaceae), Critically Endangered, with observations on its pollination and notes on the endemics of $\mathrm{Mt}$ Kupe, Cameroon. Blumea 64: 158 - 164.

Cheek, M., Feika, A., Lebbie, A., Goyder, D., Tchiengue, B., Sene, O., Tchouto, P., Burgt, X. van der (2017). A synoptic revision of Inversodicraea (Podostemaceae). Blumea 62: 125 156. https://doi.org/10.3767/blumea.2017.62.02.07

Cheek, M., Gosline, G. \& Csiba, L. (2002a). A new species of Rhaptopetalum (Scytopetalaceae) from western Cameroon. Kew Bull. 57(3): 661 - 667.

Cheek, M., Gosline, G. \& Onana, J.M. (2018a). Vepris bali (Rutaceae), a new critically endangered (possibly extinct) cloud forest tree species from Bali Ngemba, Cameroon. Willdenowia 48: 285 - 292. https://doi.org/10.3372/wi.48.48207

Cheek, M., Harvey, Y.B., Onana, J-M. (2010). The Plants of Dom. Bamenda Highlands, Cameroon: A Conservation Checklist. Royal Botanic Gardens, Kew. 
bioRxiv preprint doi: https://doi.org/10.1101/2021.06.01.446645; this version posted June 2,2021 . The copyright holder for this preprint (which was not certified by peer review) is the author/funder, who has granted bioRxiv a license to display the preprint in perpetuity. It is made available under aCC-BY 4.0 International license.

Cheek M, Harvey Y, Onana J-M. 2011. The Plants of Mefou Proposed National Park. Yaoundé, Cameroon: A Conservation Checklist. Royal Botanic Gardens, Kew.

Cheek, M., Mackinder, B., Gosline, G., Onana, J.M., Achoundong, G. (2001). The phytogeography and flora of western Cameroon and the Cross River-Sanaga River interval. Systematics and Geography of Plants 71: 1097 - 1100. https://doi.org/10.2307/3668742

Cheek, M., Nic Lughadha, E., Kirk, P., Lindon, H., Carretero, J., Looney, B.,Douglas, B., Haelewaters, D., Gaya, E., Llewellyn, T., Ainsworth, M., Gafforov, Y., Hyde, K., Crous, P., Hughes, M., Walker, B.E., Forzza, R.C., Wong, K.M., Niskanen, T. (2020c). New scientific discoveries: plants and fungi. Plants, People Planet 2: $371-388$.

https://doi.org/10.1002/ppp3.10148

Cheek, M., Oben, B. \& Heller, T. (2009). The identity of the West-Central African Oricia lecomteana Pierre, with a new combination in Vepris (Rutaceae). Kew Bull. 64: 509 - 512 https://doi.org/10.1007/s12225-009-9135-1

Cheek, M., Onana, J-M., Yasuda, S., Lawrence, P., Ameka, G., Buinovskaja G. (2019a). Addressing the Vepris verdoorniana complex (Rutaceae) in West Africa, with two new species. Kew Bull. 74: 53. https://doi.org/10.1007/S12225-019-9837-Y

Cheek, M., Onana, J-M., Pollard, B.J. (2000). The Plants of Mount Oku and the Ijim Ridge, Cameroon, a Conservation Checklist. Royal Botanic Gardens, Kew.

Cheek, M., Pollard, B.J., Darbyshire, I, Onana, J.M. \& Wild, C. (2004). The Plants of Kupe, Mwanenguba and the Bakossi Mts, Cameroon. A Conservation Checklist. Royal Botanic Gardens, Kew.

Cheek, M., Prenner, G., Tchiengué, B., Faden, R.B. (2018c). Notes on the endemic plant species of the Ebo Forest, Cameroon, and the new, Critically Endangered, Palisota ebo (Commelinaceae. Plant Ecology \& Evolution 151: 434 - 441.

https://doi.org/10.5091/plecevo.2018.1503

Cheek, M., Tchiengue, B., Baldwin, I. (2020b). Notes on the plants of Bakossi, Cameroon, and the new Cola etugei and Cola kodminensis (Sterculiaceae-Malvaceae). Plant Ecology and Evolution 153: 108 - 119 https://doi.org/10.5091/plecevo.2020.1662

Cheek, M., Tchiengué, B., van der Burgt, X. (2021). Taxonomic revision of the threatened African genus Pseudohydrosme Engl. (Araceae), with P. ebo, a new, critically endangered species from Ebo, Cameroon. PeerJ 9:e10689 https://doi.org/10.7717/peerj.10689.

Cheek, M., Thomas, D., Besong, J.B., Gartlan, S. \& Hepper, F.N. (1994). Mount Cameroon, Cameroon pp. 163 - 166 in S. D. Davies, V.H. Heywood \& A.C. Hamilton (eds.) Centres of Plant Diversity: A Guide and Strategy for their Conservation. WWF/IUCN. Cambridge. 
Cheek, M., Tsukaya, H., Rudall, P.J., Suetsugu, K. (2018d). Taxonomic monograph of Oxygyne (Thismiaceae), rare achlorophyllous mycoheterotrophs with strongly disjunct distribution. PeerJ 6: e4828. https://doi.org/10.7717/peerj.4828

Cheek M., Williams S. \& Etuge M. (2003). Kupea martinetugei, a new genus and species of Triuridaceae from western Cameroon. Kew Bull. 58: 225 - 228.

https://doi.org/10.2307/4119366

Cheplogoi, P.K., Mulholland, D.A., Coombes, P.H., Randrianarivelojosia, M. (2008). An azole, an amide and a limonoid from Vepris uguenensis (Rutaceae). Phytochemistry 69: 1384 - 1388. https://doi.org/10.1016/j.phytochem.2007.12.013

Courade, G. (1974). Commentaire des Cartes. Atlas Regional. Ouest 1. ORSTOM. Yaoundé, Cameroun.

Couvreur, T.L.P., Dagallier, L.-P.M.J., Crozier, F., Ghogue, J.-P., Hoekstra, P.H., Kamdem, N.G., Johnson, D.M., Murray, N., Sonké, B. (2021). Flora of Cameroon - Annonaceae. Phytokeys

Cribb, P. \& Pollard, B. (2002). New Orchid Discoveries in Western Cameroon. Kew Bull. 57: 653 -659. https://doi.org/10.2307/4110995

Cribb, P. J. \& Pollard, B. J. (2004). Bulbophyllum kupense P.J.Cribb \& B.J.Pollard, an unusual new Orchid from western Cameroon. Kew Bull. 59: 137 - 139

Dagallier, L.P., Janssens, S.B., Dauby, G., Blach-Overgaard, A., Mackinder, B.A., Droissart, V., Svenning, J.C., Sosef, M.S., Stévart, T., Harris, D.J. \& Sonké, B. (2020). Cradles and museums of generic plant diversity across tropical Africa. New Phytologist 225: 2196 - 2213.

Damen, T.H., Van der Burg, W.J., Wiland-Szymańska, J. \& Sosef, M.S.M. (2018).

Taxonomic novelties in African Dracaena (Dracaenaceae). Blumea-Biodiversity, Evolution and Biogeography of Plants 63: 31 - 53.

Darbyshire, I., Anderson, S., Asatryan, A., Byfield, A., Cheek, M., Clubbe, C., Ghrabi, Z., Harris, T., Heatubun, C. D., Kalema, J., Magassouba, S., McCarthy, B., Milliken, W., Montmollin, B. de, Nic Lughadha, E., Onana, J.M., Sa1dou, D., Sarbu, A., Shrestha, K. \& Radford, E. A. (2017). Important Plant Areas: revised selection criteria for a global approach to plant conservation. Biodivers. Conserv. 26: 1767 - 1800. https://doi.org/10.1007/s10531017-1336-6.

Droissart V., Sonké, B., Lowry, II P. P., Pollard, B. J. \& Stévart, T. (2012). Notes taxonomiques et chorologiques sur quelques Orchidaceae endémiques d'Afrique centrale atlantique. Adansonia, sér. 3, 34: 23 - 35. http://dx.doi.org/10.5252/a2012n1a3

Enang, R.K., Yerima, B.P.K., Kome, G.K. and Van Ranst, E. (2020). Trace elements 
bioRxiv preprint doi: https://doi org/10.1101/2021.06.01.446645; this version posted June 2,2021 . The copyright holder for this preprint (which was not certified by peer review) is the author/funder, who has granted bioRxiv a license to display the preprint in perpetuity. It is made available under aCC-BY 4.0 International license.

in tephra soils of mounts Kupe and Manengouba (Cameroon). Eurasian Soil Science 53: 595 - 606. https://doi.org/10.1134/s1064229320050051

Franke, T. (2004). Afrothismia saingei (Burmanniaceae, Thismieae), a new mycoheterotrophic plant from Cameroon. Systematics and Geography of Plants 74: 27 - 33.

Gosline, G. \& Cheek, M. (1998). A new species of Diospyros (Ebenaceae) from Southwest Cameroon. Kew Bull.53(2): 461 - 465. https://doi.org/10.2307/4114512

Gosline, G., Cheek, M., Onana, J.-M., Ngansop, E., van der Burgt, X., Dagallier, L.-P.J.M. (2021). Uvariopsis ebo (Annonaceae) a new, Critically Endangered tree species from the Ebo Forest, Cameroon and a key to the Cameroonian species of Uvariopsis. BioRxiv (pre-print) https://doi.org/https://doi.org/10.1101/2021.03.26.437154

Harris, D.J. \& Wortley, A.H. (2018). Monograph of Aframomum (Zingiberaceae) Systematic Botany Monographs 104: 1 - 204.

Harvey, Y.B., Pollard, B.J., Darbyshire, I., Onana, J.-M., Cheek, M. (2004). The Plants of Bali Ngemba Forest Reserve. Cameroon: A Conservation Checklist. Royal Botanic Gardens, Kew.

Harvey, Y.B., Tchiengue, B., Cheek, M. (2010). The Plants of the Lebialem Highlands, a Conservation Checklist. Royal Botanic Gardens, Kew.

Humphreys, A.M., Govaerts, R., Ficinski, S.Z., Lughadha, E.N. and Vorontsova, M.S. (2019). Global dataset shows geography and life form predict modern plant extinction and rediscovery. Nature Ecology \& Evolution 3.7: 1043 - 1047. https://doi.org/10.1038/s41559$\underline{019-0906-2}$

Imbenzi, P.S., Osoro, E.K., Aboud, N.S., Ombito, J.O., Cheplogoi, P.K. (2014). A review on chemistry of some species of genus Vepris (Rutaceae family). Journal of Scientific and Innovative Research 3: 357 - 362

IPNI (continuously updated). The International Plant Names Index. http://ipni.org/ (accessed: 05/2020).

IUCN. (2012). IUCN Red List Categories and Criteria: Version 3.1. Second edition. - Gland, Switzerland and Cambridge, UK: IUCN. Available from: http://www.iucnredlist.org/ (accessed: May 2021).

Maas-van der Kamer, H., Maas, P.J.M., Wieringa, J.J., Specht, C.D. (2016). Monograph of African Costus. Blumea - Biodiversity, Evolution and Biogeography of Plants 61: 280 - 318. https://doi.org/10.3767/000651916X694445 
bioRxiv preprint doi: https://doi org/10.1101/2021.06.01446645: this version posted June 2.2021 . The copyriaht holder for this preprin (which was not certified by peer review) is the author/funder, who has granted bioRxiv a license to display the preprint in perpetuity. It is made available under aCC-BY 4.0 International license.

Kenfack, D, Gosline G, Gereau RE, Schatz G. (2003). The genus Uvariopsis in Tropical Africa, with a recombination and one new species from Cameroon. Novon 13: 443 - 449. https://doi.org/10.2307/3393377

Kew Science News (2020). Ebo Forest Logging Plans Suspended. https://www.kew.org/readand-watch/ebo-forest-logging-suspended (accessed 5 May 2021).

Lachenaud, O. (2019). Révision du Genre Psychotria (Rubiaceae) en Afrique Occidentale et Centrale. Opera Botanica Belgica 17: 1 - 900.

Lachenaud, O. \& Onana J. M. (2021). The West and Central African species of Vepris Comm. ex A.Juss. (Rutaceae) with simple or unifoliolate leaves, including two new combinations. Adansonia 43: 107 -

116. https://doi.org/10.5252/adansonia2021v43a10. http://adansonia.com/43/10

Lachenaud, O., Droissart, V., Dessein, S., Stévart, T., Simo, M., Lemaire, B., Taedoumg, H. and Sonké, B. (2013). New records for the flora of Cameroon, including a new species of Psychotria (Rubiaceae) and range extensions for some rare species. Plant Ecology and Evolution 146: 121 - 133. https://doi.org/10.5091/plecevo.2013.632

Langat, M.K. (2011). Flindersiamine, a Furoquinoline Alkaloid from Vepris uguenensis (Rutaceae) as a Synergist to Pyrethrins for the Control of the Housefly, Musca domestica L. (Diptera: Muscidae). Journal of the Kenya Chemical Society. 6: 9 - 15.

Langat, M.K., Mayowa, Y., Sadgrove, N., Danyaal, M., Prescott, T.A., Kami, T., Schwikkard, S., Barker, J. \& Cheek, M. (2021). Multi-layered antimicrobial synergism of (E)-caryophyllene with minor compounds, tecleanatalensine B and normelicopine, from the leaves of Vepris gossweileri (I. Verd.) Mziray. Natural Product Research, pp.1 - 11. https://doi.org/10.1080/14786419.2021.1899176

Letouzey, R. (1963). Rutaceae. Flore du Cameroun 1. Muséum Nationale D’Histoire Naturelle, Paris.

Lovell, R. (2020). Timber! The threat to Cameroon's Ebo Forest. https://www.kew.org/readand-watch/ebo-forest-cameroon (accessed 5 May 2021).

Lye, K. A. \& Pollard, B. J. (2006). Studies in African Cyperaceae 31. Cyperus microcristatus, a new species from Mt Kupe, Cameroon. Nord. J. Bot. 24: 269 - 272.

Maisels, F.M., Cheek, M., Wild, C. (2000). Rare plants on Mt Oku summit, Cameroon. Oryx 34: 136 - 140. https://doi.org/10.1017/s0030605300031057.

Manning, S.D. (1996). Revision of Pavetta subgenus Baconia (Rubiaceae-Ixoroideae in Cameroon Ann. Missouri Bot. Gard. 83: 87 - 150. 
bioRxiv preprint doi: https://doi.org/10.1101/2021.06.01.446645; this version posted June 2,2021 . The copyright holder for this preprint (which was not certified by peer review) is the author/funder, who has granted bioRxiv a license to display the preprint in perpetuity. It is made available under aCC-BY 4.0 International license.

Morton, C.M. (2017). Phylogenetic relationships of Vepris (Rutaceae) inferred from chloroplast, nuclear, and morphological data. PLoS ONE 12:

e0172708. https://doi.org/10.1371/journal.pone.0172708

Moxon-Holt, L. \& Cheek, M. (2020). Pseudohydrosme bogneri sp. nov. (Araceae), a spectacular Critically Endangered (Possibly Extinct) species from Gabon, long confused with Anchomanes nigritianus. BioRxiv (pre-print) https://doi.org/10.1101/2021.03.25.437040

Mwachala, G., Cheek, M., Fischer, E., Muasya, A.M. (2007) A new species of Dracaena L. (Ruscaceae) from Cameroon. Kew Bull. 64: 613 - 616. http://www.jstor.org/stable/20443393

Mziray, W. (1992). Taxonomic studies in Toddalieae Hook.f. (Rutaceae) in Africa. Symb. Bot. Upsal. 30: 1 - 95.

Nic Lughadha, E., Bachman, S.P. \& Govaerts, R. (2017). Plant Fates and States: Response to Pimm \& Raven. Trends in Ecology and Evolution 32: 887 - 889

https://doi.org/10.1016/j.tree.2017.09.005

Nic Lughadha, E., Bachman, S.P., Leão, T.C., Forest, F., Halley, J.M., Moat, J., Acedo, C., Bacon, K.L., Brewer, R.F., Gâteblé, G. and Gonçalves, S.C. (2020). Extinction risk and threats to plants and fungi. Plants, People, Planet 2: $389-408$.

https://doi.org/10.1098/rstb.2017.0402

Nic Lughadha, E., Govaerts, R., Belyaeva, I., Black, N., Lindon, H. Allkin, R. Magill R.E. \& Nicolson. (2016). Counting counts: Revised estimates of numbers of accepted species of flowering plants, seed plants, vascular plants and land plants with a review of other recent estimates. Phytotaxa 272: 82 - 88. https://doi.org/10.11646/phytotaxa.272.1.5

Ombito, J.O., Chi, G.F. \& Wansi, J.D. (2020). Ethnomedicinal uses, phytochemistry, and pharmacology of the genus Vepris (Rutaceae): A review. Journal of Ethnopharmacology, p.113622. https://doi.org/10.1016/j.jep.2020.113622

Onana, J.M. \& Cheek, M. (2011). Red Data Book of the Flowering Plants of Cameroon, IUCN Global Assessments. Royal Botanic Gardens, Kew.

Onana, J.M. \& Chevillotte, H. (2015). Taxonomie des Rutaceae - Toddalieae du Cameroun revisitée: découverte de quatre espèces nouvelles, validation d'une combinaison nouvelle et véritable identité de deux autres espèces de Vepris Comm. ex A. Juss. Adansonia, sér. 3. 37: 103 - 129. https://doi.org/c10.5252/a2015n1a7

Onana, J. M., Cheek, M., \& Chevillotte, H. (2019). Additions au genre Vepris Comm. ex A. Juss. (Rutaceae-Toddalieae) au Cameroun. Adansonia 41: 41-52.

https://doi.org/10.5252/adansonia2019v41a5

Plants of the World Online (continuously updated). Facilitated by the Royal Botanic Gardens, Kew. http://www.plantsoftheworldonline.org/?f=accepted_names\&q=Vepris 
(downloaded 1 May 2021)

Sainge, M.N., Kenfack, D. \& Chuyong, G.B. (2013). Two new species of Afrothismia (Thismiaceae) from southern Cameroon. Kew Bull. 68: 591 - 597.

https://doi.org/10.1007/s12225-013-9478-5

Shorthouse, D.P. (2010). SimpleMappr, an online tool to produce publication-quality point maps. [Retrieved from http://www.simplemappr.net accessed 28 May 2021]

Sieffermann, G. (1973). Les Sols des Quelques Régions volcaniques de Cameroun. Mémoires de ORSTOM No. 66. Office de la Recherche Scientifique et Technique de Outre-Mer. Paris. https://doi.org/10.1002/jpln.19751380319

Soltis, D.E., Clayton, J.W., Davis, C.C., Wurdack, K.J., Gitzendanner, M.A., Cheek, M., Savolainen, V., Amorim, A.M. \& Soltis, P.S. (2007). Monophyly and relationships of the enigmatic family Peridiscaceae. Taxon 56: $65-73$.

Sosef, M.S.M., Wieringa, J.J., Jongkind, C.C.H., Achoundong, G., Azizet Issembé, Y., Bedigian, D., Van Den Berg, R.G., Breteler, F.J., Cheek, M., Degreef, J. (2006). Checklist of Gabonese Vascular Plants. Scripta Botanica Belgica 35. National Botanic Garden of Belgium.

Stoffelen, P., Cheek, M., Bridson, D., Robbrecht. E. (1997). A new species of Coffea (Rubiaceae) and notes on Mt Kupe (Cameroon). Kew Bull. 52: 989 - 994. https://doi.org/10.2307/3668527

Stone, R. D., Ghogue, J.-P. \& Cheek, M. (2008). Revised treatment of Memecylon sect. Afzeliana (Melastomataceae-Olisbeoideae), including three new species from Cameroon. Kew Bull. 63: 227 - 241. https://doi.org/10.1007/s12225-008-9033-y

Szlachetko, L. \& Olszewski, S. (2001). Orchidaceae (Vol. 2). Flore du Cameroun 35: 387 Ministere de la Recherche Scientifique et Technique (MINREST), Yaoundé, Cameroun

Tchouto P., Edwards I., Cheek M., Ndam N., Acworth J. (1999). Mount Cameroon Cloud Forest. Pp. 263 - 277 in African Plants: Biodiversity, Taxonomy, and Uses. Royal Botanic Gardens, Kew.

Thiers, B. (continuously updated). Index Herbariorum: A global directory of public herbaria and associated staff. New York Botanical Garden's Virtual Herbarium.

http://sweetgum.nybg.org/ih/ (accessed: Jan. 2021).

Turland, N.J., Wiersema, J.H., Barrie, F. R., Greuter, W., Hawksworth, D.L., Herendeen, P.S., Knapp, S., Kusber, W.-H., Li, D.-Z., Marhold, K., May, T.W., McNeill, J., Monro, A.M., Prado, J., Price, M.J. \& Smith, G.F. (ed.) (2018). International Code of Nomenclature for algae, fungi, and plants (Shenzhen Code) adopted by the Nineteenth International 
bioRxiv preprint doi: https://doi org/10.1101/2021.06.01.446645; this version posted June 2 2021. The copyright holder for this preprint

(which was not certified by peer review) is the author/funder, who has granted bioRxiv a license to display the preprint in perpetuity. It is made available under aCC-BY 4.0 International license.

Botanical Congress Shenzhen, China, July 2017. - Glashütten: Koeltz Botanical Books. [= Regnum Veg. 159].

Verdoorn, I. C. (1926). Revision of African Toddalieae. Bulletin of Miscellaneous

Information, Royal Botanic Gardens, Kew 9: 389 - 416.

https://www.jstor.org/stable/4118639

Wansi, J.D., Mesaik, M., Chiozem, D.D., Devkota, K.P., Gaboriaud-Kolar, N., Lallemand, M-C., Wandji, J., Choudhary, M.I., \& Sewald, N. (2008). Oxidative Burst Inhibitory and Cytotoxic Indoloquinazoline and Furoquinoline Alkaloids from Oricia suaveolens. Journal of Natural Products 71: 1942 - 1945. https://doi.org/10.1021/np800276f

World Conservation Monitoring Centre. (1998). Vepris trifoliolata. The IUCN Red List of Threatened Species 1998: e.T46175A11033334.

https://dx.doi.org/10.2305/IUCN.UK.1998.RLTS.T46175A11033334.en 